\title{
ANALYSIS OF FUNCTIONAL POTENTIAL OF COMMU- NICATION TECHNOLOGIES IN MODERN EDUCATIONAL PRACTICES
}

\author{
Maya Trynyak ${ }^{1}$, Viktoriia Tykhonovych ${ }^{2}$, Nataliia Skinder ${ }^{3}$, Iryna Torianik ${ }^{4}$, Tetiana Teterina $^{5}$ \\ ${ }^{1}$ Department of Philosophy, H. S. Skovoroda Kharkiv National Pedagogical University, Kharkiv, Ukraine \\ maya1973trynyak@gmail.com \\ ORCID: https://orcid.org/0000-0003-4981-8535 \\ ${ }^{2}$ Department of Tourism and Socio-Humanitarian Disciplines, Kharkiv College of Trade and Economics, Kyiv National University of \\ Trade and Economics, Kharkiv, Ukraine \\ viktoriyamega@ukr.net \\ ORCID: https://orcid.org/0000-0002-0232-3001 \\ ${ }^{3}$ Department of Tourism and Socio-Humanitarian Disciplines, Kharkiv College of Trade and Economics, Kyiv National University of \\ Trade and Economics, Kharkiv, Ukraine \\ key4culture@rambler.ru \\ ORCID: https://orcid.org/0000-0003-4027-6418 \\ ${ }^{4}$ Department of Tourism and Socio-Humanitarian Disciplines, Kharkiv College of Trade and Economics, Kyiv National University of \\ Trade and Economics, Kharkiv, Ukraine \\ toryanik.ira09@gmail.com \\ ORCID: https://orcid.org/0000-0002-2169-748X \\ ${ }^{5}$ Department of Tourism and Socio-Humanitarian Disciplines, Kharkiv College of Trade and Economics, Kyiv National University of \\ Trade and Economics, Kharkiv, Ukraine \\ ekoleleka@gmail.com \\ ORCID: https://orcid.org/0000-0002-6116-264X
}

ARTICLE INFO

Article history:

Received date 18.03 .2021

Accepted date 20.04.2021

Published date 30.04.202

Section:

Communication

DOI

$10.21303 / 2313-8416.2021 .001805$

KEYWORDS

communication technologies

modern educational practices

discourse

postmodern society

multiculturalism

hermeneutics

\section{A B S TRACT}

The object of research is communication technologies. It is devoted to the analysis of their functional potential in educational practices. On the basis of the author's integrated methodology, communication, its structure, varieties, functional range and constructive potential are considered. The role of dialogue and discourse as a form of reflection is highlighted. It turns out the importance of hermeneutics for educational activities. It is necessary that taking into account the peculiarities of modern communication is of fundamental importance for increasing the effectiveness of educational and educational practices.

Investigated problem. The communicative philosophy proposes landmarks different from the classical philosophy of consciousness. They provide for the recognition of the phenomenon of communication as fundamental to human existence. Here communication is seen as the last foundation of consciousness, cognition and social life. This question was developed by a number of researchers earlier, but the problem remains relevant. This is due to the need to substantiate the universal foundations of human understanding. Also, the aim of research is to find new ways to harmonize relations between people.

Main scientific results. The scientific novelty of the research lies in the creation of an integrated post-non-classical model of modern communication. The features of the complex of modern communication technologies are investigated. On the basis of the author's methodological program, the functional potential of modern communication technologies in educational and upbringing practices was discovered.

The scope of practical application of the research results. The proposed methodological program is used in the development of strategies for the education of a communicative culture, in the teaching of special courses in modern communicative philosophy, pedagogy, sociology of education and culture. The research results were introduced into the educational process of the H. Skovoroda Kharkiv National Pedagogical University, Ternopil Volodymyr Hnatiuk National Pedagogical University, Kharkiv College of Trade and Economics of Kyiv National University of Trade and Economics.

An innovative analysis of the functional potential of communicative practices, together with the developed recommendations, is appropriate to apply in modern education, which is aimed at the formation of a strong and courageous personality, capable of building a successful life strategy.

(c) The Author(s) 2021. This is an open access article under the Creative Commons CC BY license 


\section{Introduction}

Modern socio-cultural contexts provide for the need for a person to master the skills and communication skills, which is a daily attribute of life. Communication is a way of being in modern societies that are experiencing significant shifts as a result of the radical changes they are going through now. This requires a revision of the already familiar approach to understanding the phenomenon of communication, a deeper analysis of its significance in the life of a modern person. The potential risks of disrupting its success should not be underestimated. Many societies, especially in the post-Soviet space, today are experiencing a process of accelerated development of national consciousness, which takes place in transnational integration contexts. All this leads to increased interest in a new type of communication as such and in the functional potential of modern communication technologies. The importance of the role of communication in educational and upbringing practices is beyond doubt, since social education at the modern level of development of human civilization provides for the acquisition of communicative competencies. So, if communication takes place in education, according to its reality, philosophical and pedagogical reflection is superimposed, integrated into the content of the communicative process.

\section{1. The object of research}

The object of this research is communication technologies with their functional potential for application in modern educational practice

\section{2. Problem description}

1. 2. 1. Socio-cultural prerequisites for the constitution of a new communicative reality

Despite the fact that the degree of elaboration of the problem being analyzed is quite high, new circumstances give rise to promising lines of research. In particular, the study of the significant role of communication in modern sociocultural contexts requires special attention.

Communication is one of the most important components of human life, which has a huge impact on the formation of personality. The definition of this concept has many interpretations. In a general sense, this is a process of exchange of opinions, information, ideas, etc., the transfer of one or another content from one consciousness (collective or individual) to another with the help of signs fixed on material carriers.

Another heuristically rich definition of communication is offered by the German classic of $20^{\text {th }}$ century sociology, the author of the original theory of society, the founder of the system of self-referential systems, Nickolas Luchman. In his theory, communication is the way social systems exist. According to Luhman, "any social contact should be understood as a system, the boundaries of such systems can reach up to society, which is a set of taking into account all possible contacts" [1].

So in his theory, all societies, organizations and interactions are considered as social systems on the basis that they consist of communications. People remain outside the Luhman analysis - they are defined in this theory as mental systems. People are seen as the environment of society, not as part of it. So, the weak side of this theory is the deliberate removal from the field of research of the anthropological component of communication. But from a methodological point of view, this allows to focus on the mechanisms of productive meanings. This means that methodologically, one can focus on the mechanisms of productive meanings, namely, focus on communication as such. It becomes possible to consider communication as a self-regulating system, it is of fundamental importance for understanding its phenomenon.

So, communication as a social system, on the one hand, is an independent self-referential formation, and on the other hand, it still unfolds under the influence of certain external factors, the authors define as socio-cultural prerequisites for the constitution of a new communicative reality.

At the beginning of the XXI century, a globalization-information paradigm is being formed, which is gradually replacing the technocratic (modernist) paradigm that preceded it. This change is due to a number of socio-cultural and anthropological factors, which, in turn, are a consequence of the transition of mankind to a new type of civilization. In the literature, this is the so-called "information society", which is at the same time a society of knowledge, risks and multiculturalism. If in an industrial society the objects of accumulation were money, resources and power, then in an information society they are opposed by knowledge. Universities, where new knowledge is 
produced, are replacing factories and plants. On the existential plane, there is an increase in risks due to the accumulation of instability of dynamism and unpredictability [2]. That is why they talk about the so-called "risk society".

Analyzing the socio-cultural prerequisites for the constitution of a new communicative reality, one cannot fail to mention globalization, which also affects communication processes. It should be noted that it should be understood as a variety, and not as unification. As a result of globalization processes, another factor arises that affects the nature of modern communication processes, this is multiculturalism, which constitutes a separate phenomenon and a separate ideology.

In the era of early modernity, multicultural realities were perceived through the prism of imperial thinking. In the later, the modern strengthens not only the way of constituting multiculturalism, but also its representation. They are formed in a democratic culture, which in turn engenders a new culture of freedom.

An equally influential prerequisite for the constitution of a new communicative reality is such a characteristic of modern society as a "knowledge society". Communication technologies are of great importance for ensuring the efficiency of the knowledge transfer process; they are an integral part of modern educational and educational practices.

So, the features of the prerequisites for the constitution of a new communicative reality are substantiated by modern socio-cultural contexts that shape the nature of society both in the local and planetary dimensions.

\section{2. 2. Hermeneutics and semantics of communication: from contextual epistemology} to self-description and self-understanding

The new communicative paradigm assumes a variety of communication manifestations in everyday life. So, communication arises and is maintained in the human life world. This explains the dominance of the natural attitude in its consideration. It is investigated mainly on the basis of factual material as a separate communicative action. Therefore, communication is described fragmentarily on the basis of contextual epistemology, and its main meanings cease to be transparent, causing conflicts of interpretations [3].

Communication is a structured process that has its own levels and forms. Avoid conflicting interpretations. It is also important to overcome methodological and epistemological difficulties. For this, it is necessary to carry out a hermeneutic analysis of the content of communication as a practice. It is necessary to identify its methodologically significant semantics. These semantics help to realize self-description and define self-understanding of educational and upbringing processes. Such processes are initiated, among other things, by the demands of multiculturalism [4].

The hermeneutic analysis of cultural communication indicates the need to determine those meanings that ensure its pre-understanding. As S. Kosharny notes: "in a certain way, the meanings (object meanings) are fixed and coordinated, they are subject to recognition, assimilation and reproduction by the interpreter in their original essence with the help of a certain kind of mental activity, the fundamental operation of which is understanding" [5]. It is the hermeneutics of the communication situation that allows the scheme of the hermeneutic circle presupposes an understanding of the parts on the basis of a preliminary understanding of the whole. The whole, in turn, presupposes an understanding of the parts. Therefore, this diagram shows the importance of contextual analysis for understanding the whole meaning. It also demonstrates the subject orientation of communication as such. Culture is a context that helps to understand individual concrete manifestations of another culture. At the same time, it is the whole to which participants in cultural communication step by step approach. Understanding the process of reaching agreement between representatives of different cultures, the German researcher C. Geertz emphasizes that "culture is a self-woven fabric of meanings, into which a person is woven" [6]. In other words, each specific individual is inseparably one with the world of culture. Therefore, the need to consider the meanings of cultural dialogue from the angle of their cultural and anthropological functionality is due to the fact that in society, communication performs primarily an integrative-recognition function. A. Gofron refers it to the customs of communication, the autopoiesis of which allows the use of its capabilities in education [7].

Inductive cultural anthropology, within the framework of which the content of cultural communication is usually deciphered, it is thanks to the hermeneutic method that it is able to bring 
facts and observations to the level of generalizations. Let's recall that neither the existing culture nor its reconstruction can be understood outside of cultural communications, where problems are thematized, meanings are generated, the prospects for the existence of certain cultures are determined, going beyond their immediate reality. Cultural communication is the process of creating and transmitting a complex of psychological, moral, ethical, aesthetic aspects of the interaction of different cultures and ethnic groups, which have an increasingly pronounced tendency to continue their cultural space. Cultural identity proper in those conditions when "everyone shares their living space with other people, having relations (sometimes friendly, sometimes hostile) at least with a neighbor" [8] requires concretization and not. Thus, the problem of preserving the culture of an ethnos paradoxically requires a hermeneutic analysis of all possible cultural communications.

\section{2. 3. Phenomenology of dialogue in educational and upbringing practices}

There is a constant tension between our own and the alien, which is of fundamental importance for understanding the specifics of cultural dialogue. Around the definition of its formal structure and framework conditions, there is still a lot of controversy, in particular concerning the role of the impersonal instance of the Third, which makes the maintenance of the symmetry of the dialogue. The Instance of the Third in phenomenological xenology is fundamentally different from the ideal-typical construct of the ideal communicative community in the transcendental pragmatics of K.-O. Apel and J. Habermas, which is counterfactual. Neutral Third acts as the factuality of intersubjectivity and at the same time is the basis of cultural dialogue. Waldenfels notes in this regard: "The neutral third bears the title of truth, law, conscience, intentional meaning, or covetousness of significance. The relationship between the participants in the dialogue in principle gravitates towards a symmetric equation. This is because every attempt at understanding and every claim of the significance of the "I" prompts an attack on its own position. This leads to the fact that the Alien is not completely alien, and His is not purely ours" [9]. The potential interchangeability of perspectives is a formal prerequisite for any dialogue. The constitution of role reality presupposes the presence of a third in the dialogue. It is the latent presence of the Third that makes it possible to elevate any polylogue to dialogue. Instance of a neutral third helps to minimize the risks of cultural communication. The formal phenomenology of cultural dialogue raises a number of questions. Among them, the definition of whether cultural dialogue fits into transcultural perspectives is of fundamental importance. In the first case, for the exchange of one's own and another's, there would be a form of community of the highest degree, to which they are approaching, and in the other case, only exchange would remain common "[9].

Let's try to apply these provisions in describing the structure, intentions and role reality of educational cultural dialogue. To demonstrate the power of the functional potential of dialogue as a communicative practice, one can cite, in particular, the model of a communicative-excursion workshop proposed by the modern Lviv researcher S. Cherepanova [10]. First of all, it should be noted that, in contrast to the formalized model of cultural dialogue, its educational version requires concretization and clarification. In the case of an educational cultural dialogue, the task of establishing an intellectual field is simplified, which is a prerequisite for the deployment of cultural communicative acts, the main structural elements of which are claims and responses. But the Own, the Alien and the instance of the order of the Third in the educational cultural dialogue constitute a reality that does not go beyond communicative acts and appears in the form of a multidimensional model.

The instance of a neutral third in educational dialogue is more authoritative than in a situation of any other dimension of cultural dialogue. The neutral third becomes more active here than in any other case, because he acts as an objective pedagogical mind, invoking the authority of the recognized and the general. Educational cultural dialogue in this case is reduced to a trivial exchange of experience in educational and upbringing practices or to the hermeneutic export of pedagogical ideas. But the phenomenological approach allows to go beyond these concepts and describe the very process of constituting an integrated educational space, as well as the transformation of educational practices that take place in the process of such a dialogue.

The phenomenological attitude also allows for a new interpretation of various "side effects" in upbringing. In neo-Hegelian oriented humanistic pedagogy (E. Spranger, T. Litt), they were mainly viewed as "unwanted side effects" [11]. The phenomenological theory of extensional education fundamentally changes the emphasis. That is why Treml concludes that "existential education 
is the pedagogy of the desired side effects" [11]. Upbringing and education, in the context of the extraterritorial nature of globalization processes and the intensification of migration, exacerbates the problem of a person's being rooted. Its connection with its homeland, according to supporters of the theory of extensional education, can occur virtually. This is due to the pedagogical construction of a "place of cultural comfort". In such a "place" a person can take a break from the overload of the local and global experience of a stranger both in everyday life and in other spheres of social life. True, Treml notes in this regard: "Such pedagogically staged places of the "homeland" are undeniably constructions, because the concept of homeland should be as plural as possible for the observer." [11] The so-called "desired side effects" are designed to create such constructions.

So, the consideration of cultural educational dialogue in a phenomenological perspective allows to identify new opportunities for educational practices, to show the importance of visualizing the connection between tradition, its spatial consolidation in globalized extraterritoriality.

\section{3. Suggested solution to the problem}

The features of modern communication inherent in postmodern societies, which are informational and multicultural societies, risk and knowledge societies, are analyzed. An analysis of the problem of understanding the phenomenon of communication, which manifests itself, in particular, in modern communication technologies, is proposed in many studies of philosophers, sociologists, political scientists, teachers, representing different trends and directions and, accordingly, starting from different initial positions. So, for example, in modern communicative philosophy, communication as a phenomenon is considered in the studies of K.-O. Apel, who laid the communicative turn in communicative philosophy $[12,13]$. E. Bystritsky and S. Proleev analyze the relationship between the concepts of "globalization", "communication" and "culture", while giving the main role to culture, and try to rethink the traditional views on communication [14]. M. Kultaeva special focus of research has the phenomenon of sociology of globalization [4]. J. Habermas draws attention to the special role of communication in the establishment of stable interpersonal relationships [15]. A. Yermolenko, in turn, sheds light on the problems of modern practical philosophy in the context of applied ethics, comparing the provisions of the classical philosophy of morality and modern representatives [16]. N. Luchman puts forward communication as the mover of social forces [17], and L. Sytnichenko notes the appeal to the semantic sources of the new philosophy of communication, recognizing the principle of intersubjective, cultural and communicative structures [18]. P. Freire postulates a new philosophy of education, promotes the liberation of a person from psychological, ideological and cultural oppression, drawing attention to the fact that only as a result of an equal dialogue a person can achieve free personal development [19].

Considering that a certain focus of our research is the analysis of such a phenomenon as hermeneutics and the features of the hermeneutic circle, one cannot but mention the research of H-G. Gadamer, who claims that the phenomenon of understanding permeates all human connections with the world, hermeneutics embodies the experience of truth, is philosophically grounded and at the same time acts way of philosophizing [20]. M. Heidegger examines the phenomenon of understanding in the ontological plane, the main task of hermeneutics, in his opinion, is the interpretation of the understanding of being originally inherent in human being [21]. W. Humboldt used hermeneutic problems to study natural language and introduced a new principle of dialogue as a method for analyzing linguistic phenomena [22]. W. Dilthey considers hermeneutics as a theory of historical knowledge, should become the basis of the theory of knowledge in the historical sciences [5], and F. Schleiermacher focuses on the universality of hermeneutics, the subject of which is each text, and not just a certain part of it [23].

Deepening the understanding of the importance of dialogue as a communication technology, it is appropriate to refer to the achievements of such researchers as M. Bakhtin, who singles out dialogue as a kind of communication between individuals, as a way of interaction between a person and objects of culture and art, different cultures during historical development [24]. W. Bibler develops the concept of a dialogue of cultures, are constantly in dialogue with each other [25]. M. Buber focuses on the fact that a person's dialogue with other people, with God, with nature is a specifically human way of being [26]. V. Hösle examines the process of creating a philosophical dialogue, its social prerequisites and obstacles [27]. E. Levinas put the meeting between me and the Other in the center [28], and K. Jaspers highlighted the cognitive meaning and the possibility 
of self-knowledge of universal human interests in the communicative process [29]. Among modern Ukrainian researchers, the scientific achievements of S. Cherepanova should be highlighted, which demonstrates an original approach to understanding the dialogue and its functional potential in excursions, in particular [10].

Despite the presence of a wide range of studies related to the selected topic, this problem has to be further investigated through its dialectical nature, which changes under the influence of the influence of modern socio-cultural contexts, which are constantly updated.

Modern communication has the character of global communication, based on the maximum freedom of information. In conditions of freedom of speech, everyone is involved in what is happening. This is the modern socio-cultural context containing certain challenges, it is possible to mitigate their overcoming if a person is ready for that. The person must be ready to use their voice in collective communication. So, "we are talking about the fundamental right to your voice in a collective ensemble of communication. Thanks to freedom of speech, communication is based on the presumption of (democratic) communicative equality - the equal right of everyone to participate in everything that happens [14]. The concept of the formation of a person's readiness to communicate in such conditions should be introduced into educational and upbringing practices. One of these is the so-called «global communication», which requires special communication skills from a person. Another task of the teacher today is the formation of a logical culture, which has been positioned as an analogue of linguistic culture since the time of representatives of the Lvov-Warsaw school, an in-depth analysis of the phenomenon of which is offered by the modern researcher O. Honcharenko [30]. Skill building will help the stress-free person respond to this rebuke. For this purpose, the author's analysis of the phenomenon of communication as the basis of the life of a successful person has been developed.

So, the aim of research is to determine the features of the modern phenomenon of communication, the functional potential of communication technologies in terms of their use in educational and educational practices to increase their effectiveness and to develop recommendations for their successful implementation based on philosophical, anthropological and systemic theoretical analysis.

\section{Materials and methods}

The study was carried out on the basis of a comprehensive methodology, which is based on a complementary combination of hermeneutic, phenomenological, contextual, structural-functional and system-theoretical analysis, as well as the method of anthropological interpretation and the historical-genetic method. The interdisciplinary approach and methodological foundations of comparative studies have become cross-cutting in the research. The application of this methodology is due to the very nature of cultural communication in its empirical given and theoretical predestination. A review is done through the method of ascent from the abstract to the concrete results of cultural, sociological, historical and psychological-pedagogical research in this plane.

\section{Research results}

Structural-functional and existential-anthropological analysis of communication technologies was carried out on a complementary basis. The necessity of updating the perception of this phenomenon, overcoming the theoretical and methodological patterns and stereotypes that have developed in the pre-modern day has been taken into account. As a result of the analysis, a metatheoretical program has been developed, the use of which makes it possible to significantly deepen the understanding of the communication construct in modern educational and educational practices. The features of the socio-cultural prerequisites for the constitution of a new communicative reality are substantiated and disclosed, they are stipulated by modern socio-cultural contexts that make up the nature of society in local and global dimensions. It is highlighted that the appeal to the hermeneutics and semantics of cultural educational communication made it possible to conclude that cultural educational communication is constantly expanding its semantic horizons, realizing the hermeneutic enlightened description, self-description and self-observation of its theoretical and methodological proposals. It is proved that the consideration of cultural educational dialogue in a phenomenological perspective contributes to the identification of new possibilities of educational practices, demonstrating the importance of visualizing the connection with tradition and its spatial 
consolidation in globalized extraterritoriality. A significance of the functional potential of modern communication technologies in educational practices is revealed as one of the possible responses to the challenges of modern society.

\section{Discussion of research results}

Despite the social, civilizational and cultural significance of the phenomenon of communication as a response to the challenges of globalization, there are certain gaps in this thematic field.

In their study, to reveal the features and, accordingly, the functional potential of educational cultural communication, the authors relied on the materials of empirical and theoretical studies of Western European and American scientists. It is in these countries that cultural educational communication is more developed and, therefore, deserves attention as an experience in the implementation of culturally oriented educational and didactic practices. Especially here it should be noted the works of the aforementioned scientists, namely J. Habermas [15], E. Bystritsky and S. Proleev [14], M. Kultaeva [4], V. Hösle [27], A. Yermolenko [16], L. Sytnichenko [18], S. Cherepanova [10], O. Honcharenko [30].

In developing their approach to understanding the functional potential of communication technologies, the authors took into account the achievements of their predecessors, but developed their own metatheoretical model of modern communication, the reflection of which in the practical plane is the latest communication technologies. This methodological program consists of a set of empirically based communication activities. These measures are aimed at improving the comfort and efficiency of communication. So, for example, the analysis of the phenomenon of dialogue in the classical sense gives rise to its new dimensions (communicative-excursion workshop, in particular). The results of this study can be used in the further development of the problems of strategies for the upbringing of a communicative culture, the formation of skills and abilities for successful and effective communication. The proposed property will be useful in teaching such special courses as: modern communicative philosophy, intercultural communication, theoretical and comparative pedagogy, sociology of globalization, analysis of social processes, tourism, and the like.

Within the framework of the proposed study, it is impossible to exhaustively reveal the phenomenon of communication through its versatility and complexity. The researchers did not aim, in particular, to analyze such features of communication in education as a distance form, or the principle of adherence to tolerance in modern communication processes. Consequently, the formation of a culture of tolerance in dialogue remains a promising line of research.

Thus, it can be stated that research as a whole has a methodological character, which forms a powerful platform for further theoretical developments in this thematic field. But, at the same time, the proposed empirically grounded recommendations will be useful to practicing educators, philosophers, psychologists, philologists, sociologists, etc.

\section{Conclusions}

Communication is an important component of cultural educational practices, and, as reality and as reflection, it differs in the scope and nature of its representations. In modern education, it always unfolds at the macro-, meso- and microlevels, which means its semantic load and the possibility of influencing a person and society. To achieve a multidimensional cultural communication, it is necessary to use the possibilities of interdisciplinary syntheses, which are carried out on the basis of philosophical reflection.

Educational institutions, modern educational and didactic practices, unfold in the realities of a multicultural society, can remain viable only in the conditions of their readiness for cultural dialogue. It requires, first of all, methodological support, which becomes possible only on the basis of a comprehensive methodological program. Over the past decades, cultural communication has become so widespread through migration processes that one gets the impression of its spontaneous, non-harassing character. Everyday experience provides numerous examples of cultural communication practices that develop spontaneously and quite often lead to misunderstandings. The educational dimension of cultural communication is fundamentally different from everyday communication practices. In addition, the constant change of socio-cultural contexts also leads to numerous transformations. Modern modifications of communication, in particular, due to the course of the global coronavirus pandemic, are gradually replacing traditional communication. 


\section{References}

[1] Luhmann, N. (1984). Soziale Systeme. Grundriß einer allgemeiner Theorie. Frankfurt am Main: Suhrkamp, 675.

[2] Andrushchenko, V., Peredborska, I. (Eds.) (2009). Filosofiia osvity. Kyiv: Vyd-vo NPU imeni M. P. Drahomanova, 329.

[3] Tryniak, M. V. (2011). Interkulturna komunikatsiia v osviti: tendentsiia rozghortannia u suchasnykh sotsiokulturnykh kontekstakh. Kharkiv.

[4] Kultaieva, M. D. (2006). Kontury yevropeiskoho hromadianskoho suspilstva i ukrainska realnist. Tsinnosti hromadianskoho suspilstva i moralnyi vybir: ukrainskyi dosvid. Kyiv: ETNA-1, 143-151.

[5] Kosharnyi, S. O. (1992). Bilia dzherel filosofskoi hermenevtyky (V.Diltei i E. Husserl). Kyiv. Naukova dumka, 124.

[6] Geertz, C. (1995). Dichte Beschreibung. Beiträge zum Verstehen kultureller Systeme. Frankfurt am Main: Suhrkamp, 320.

[7] Hofron, A. (2006). Filosofsko-komunikatyvni aspekty osvity. Filosofiia osvity, 1 (3), 43-53.

[8] Hofe, O. (2007). Demokratiia v epokhu hlobalizatsii. Kyiv: PPS-2002, 435.

[9] Valdenfels, B. (2004). Topohrafiia Chuzhoho: studii z fenomenolohii Chuzhoho. Kyiv: PPS, 206.

[10] Cherepanova, S. (2020). Filosofiia osvity. Komunikatyvno-ekskursiinyi praktykum. Dialohy studentiv pro mystetstvo ta osvitu. Lviv - Oksford. Lviv: Rastr-7, 37.

[11] Spranger, E., Braeuer, H. G., Flitner, A. (1969). Das Gesetz der ungewollten Nebenwirkungen in der Erziehung. Geist der Erziehung. Heidelberg: Quell und Maeyer, 348-405.

[12] Apel, K.-O. (1998). Transtsendentalno-germenevticheskoe poniatie iazyka. Ot Ia k Drugomu: problemy sotsialnoi ontologii v postklassicheskoi filosofii. Minsk: Propilei, 27-36.

[13] Apel, K.-O., Yermolenko, A. M. (1999). Spriamuvannia anhlo-amerykanskoho „komunitaryzmu” u svitli dyskursyvnoi etyky. Komunikatyvna praktychna filosofiia. Kyiv: Libra, 372-394.

[14] Bystrytskyi, Ye., Zymovets, R., Proleiev, S. (2020). Komunikatsiia i kultura v hlobalnomu sviti. Kyiv: Dukh i litera, 416.

[15] Habermas, J.; Habermas, J., Luhmann, N. (Eds.) (1971). Vorbereitende Bemerkungen zu einer Theorie der kommunikativer Kompetenz. Theorie der Gesellschaft oder Sozialthechnologie. Frankfurt am Main: Suhrkamp, 98-156.

[16] Yermolenko, A. M. (1999). Komunikatyvna praktychna filosofiia. Kyiv: Libra, 488.

[17] Luhmann, N. (1998). Die Gesellschaft der Gesellschaft. Zweiter Teilband. Frankfurt am Main, 1164.

[18] Sytnychenko, L. A. (1996). Pershodzherela komunikatyvnoi filosofii. Kyiv: Lybid, 176.

[19] Freire, P. (2004). Pedahohika svobody. Etyka, demokratiia i hromadianska muzhnist. Kyiv: KM Akademiia, 124.

[20] Gadamer, G.-G.; Bessonov, B. N. (Ed.) (1988). Istina i metod. Osnovy filosofskoi germenevtiki. Moscow: Progress, 704.

[21] Kultaieva, M. D. (2002). Martin Haidehher u spohadakh koleh ta uchniv. U Martin Haidehher ochyma suchasnykiv. Kyiv: Stylos, 3-23.

[22] Gumboldt, V. fon. (1985). Iazyk i filosofiia kultury. Moscow: Progress, 448.

[23] Shleiermakher, F.; Guchinskaia, N. O. (Ed.) (2004). Germenevtika. Saint Petersburg: «Evropeiskii Dom», 242.

[24] Bakhtin, M. M. (2000). Avtor i geroi: K filosofskim osnovam gumanitarnykh nauk. Saint Petersburg: Azbuka, 336.

[25] Bibler, V. S. (1989). Kultura. Dialog kultur. Voprosy filosofii, 6, 31-42.

[26] Buber, M. (1995). Ia i ty. Moscow: Respublika, 464.

[27] Hösle, V. (2006). Der philosophische Dialog Eine Poetik und Hermeneutik. München: Verlag C. H. Beck, 494.

[28] Levinas, E. (1999). Totalnost i beskonechnoe: esse o vneshnosti. Voprosy filosofii, 2, 54-67.

[29] Yaspers, K.; Sytnychenko L. A. (1996). Komunikatsiia. Pershodzherela komunikatyvnoi filosofii. Kyiv: Lybid, $132-148$.

[30] Honcharenko, O. (2018). Filosofiia osvity u Lvivsko-Varshavskii shkoli. Kamianets-Podilskyi: Drukarnia «Ruta», 476. 